\title{
Effects of Deep Eutectic Solvents on H2SO4-catalyzed Alkylation: Combining Experiment and Molecular Dynamics Simulation
}

\author{
Zhihong $\mathrm{Ma}^{1}$, Jialei Sha ${ }^{1}$, Weizhong Zheng ${ }^{2}$, Weizhen Sun ${ }^{1}$, and Ling ZHAO${ }^{1}$ \\ ${ }^{1}$ Affiliation not available \\ ${ }^{2}$ East China University of Science and Technology
}

September 24, 2021

\begin{abstract}
To enhance the catalytic performance of H2SO4-catalyzed alkylation, various catalytic additives have drawn considerable attention. Herein, the effects of deep eutectic solvents additives (DESs) on catalytic performance and interfacial properties of $\mathrm{H} 2 \mathrm{SO} 4$ alkylation were systematically investigated using experimental methods and molecular dynamics (MD) simulation. Experimental results indicate that DESs additives with the optimal concentration about $1.0 \mathrm{wt} \%$ can efficiently improve C8 selectivity and research octane number (RON) of alkylate. However, DESs additives contribute less to the quality of alkylate at low temperature and to the lifetime of $\mathrm{H} 2 \mathrm{SO} 4$. MD results reveal that the phenyl molecules of DESs additives play a major role in enhancing interfacial properties of $\mathrm{H} 2 \mathrm{SO} 4$ alkylation, including enlargement of interfacial thickness, promotion of isobutane relative solubility and diffusion to butene, which is probably the main reason for the better quality of alkylate. This work gives a good guideline for the design of novel DESs for H2SO4 alkylation.
\end{abstract}

Effects of Deep Eutectic Solvents on $\mathrm{H}_{2} \mathrm{SO}_{4}$-catalyzed Alkylation: Combining Experiment and Molecular Dynamics Simulation

Zhihong $\mathrm{Ma}^{1}$, Jialei Sha ${ }^{1}$, Weizhong Zheng ${ }^{*},{ }$, Weizhen Sun ${ }^{*}$, , and Ling Zhao ${ }^{1,2}$

${ }^{1}$ State Key Laboratory of Chemical Engineering, School of Chemical Engineering, East China University of Science and Technology, Shanghai 200237, China

${ }^{2}$ School of Chemistry \& Chemical Engineering, XinJiang University, Urumqi 830046, China

\begin{abstract}
To enhance the catalytic performance of $\mathrm{H}_{2} \mathrm{SO}_{4}$-catalyzed alkylation, various catalytic additives have drawn considerable attention. Herein, the effects of deep eutectic solvents additives (DESs) on catalytic performance and interfacial properties of $\mathrm{H}_{2} \mathrm{SO}_{4}$ alkylation were systematically investigated using experimental methods and molecular dynamics (MD) simulation. Experimental results indicate that DESs additives with the optimal concentration about $1.0 \mathrm{wt} \%$ can efficiently improve $\mathrm{C}_{8}$ selectivity and research octane number (RON) of alkylate. However, DESs additives contribute less to the quality of alkylate at low temperature and to the lifetime of $\mathrm{H}_{2} \mathrm{SO}_{4}$. MD results reveal that the phenyl molecules of DESs additives play a major role in enhancing interfacial properties of $\mathrm{H}_{2} \mathrm{SO}_{4}$ alkylation, including enlargement of interfacial thickness, promotion of isobutane relative solubility and diffusion to butene, which is probably the main reason for the better quality of alkylate. This work gives a good guideline for the design of novel DESs for $\mathrm{H}_{2} \mathrm{SO}_{4}$ alkylation.
\end{abstract}

Keywords : $\mathrm{H}_{2} \mathrm{SO}_{4}$ alkylation, DESs, Liquid/liquid interface, MD simulation.

\section{Introduction}


The alkylate, produced by isobutane alkylation (C4 alkylation) with C3-C5 olefins using strong acid as catalyst, is an ideal blending component of the gasoline pool, owing to its numerous advantages, such as high RON, low Reid vapor pressure, free of sulfur, absence of aromatics and alkenes compounds ${ }^{1-4}$. The commercial alkylation process usually uses liquid acid as catalyst, including concentrated sulfuric acid $\left(\mathrm{H}_{2} \mathrm{SO}_{4}\right)$ and hydrofluoric acid $(\mathrm{HF})^{5,6}$. However, HF suffers from high toxicity and volatility once it releases or forms aerosol, which can result in large potential danger ${ }^{3,7}$. The solid acid as an environmentally friendly alternative shows a good selectivity and catalytic activity ${ }^{8-11}$. However, the disadvantages of easy deactivation by coking and difficult regeneration restrict its industrial application ${ }^{1,11-13}$. Ionic liquids (ILs) are also the promising alternative to catalyze $\mathrm{C} 4$ alkylation, but the disposal of spent salt is too difficult. Currently, $\mathrm{H}_{2} \mathrm{SO}_{4}$ is still the dominant catalyst for the industrial alkylation process. However, the drawbacks of equipment corrosion and high acid consumption of $\mathrm{H}_{2} \mathrm{SO}_{4}$ alkylation process motivate researchers to develop various additives, such as aromatics, surfactants, and ILs, to improve the catalytic activity of $\mathrm{H}_{2} \mathrm{SO}_{4}{ }^{6,10,13,14}$.

It is well-confirmed that surfactants as the additives of $\mathrm{H}_{2} \mathrm{SO}_{4}$ alkylation can efficiently enhance the quality of alkylate ${ }^{15,16}$. Chen et al. reported several cationic, anionic, and amphoteric surfactants as additives in C4 alkylation in $2003^{17}$. Our recent work gave a detailed investigation about the effect of surfactants on the catalytic performance and interfacial features of $\mathrm{H}_{2} \mathrm{SO}_{4}$ alkylation using experiments and molecular dynamics (MD) simulation ${ }^{15,18}$. In spite of the good performance of surfactants for C4 alkylation, the commercial surfactants, such as sodium dodecyl benzene sulfonate (SDBS) and hexadecyltrimethylammonium bromide $(\mathrm{CTAB})$, contain the sodium and bromine elements, which can accelerate equipment corrosion ${ }^{15}$. ILs have been proved as potential catalysts or additives for $\mathrm{C} 4$ alkylation ${ }^{4,19-21}$. The chloroaluminate-based ILs with Lewis acidity were the most frequently studied to enhance the $\mathrm{C} 4$ alkylation. Liu et al. reported that chloroaluminate-based ILs containing $\mathrm{CuAlCl}_{4}$ complexes show better catalytic performance ${ }^{22}$. In addition, Brønsted acidic ILs (BILs) were also demonstrated to possess excellent catalytic activity for C4 alkylation. For example, 1-(3-sulfopropyl)-3-methyl-imidazolium hydrogen sulfate and 1-(3-sulfobutyl)-3-methylimidazolium

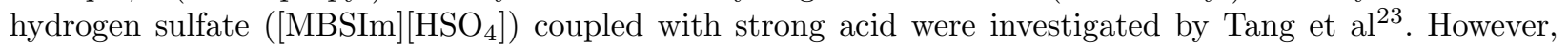
despite the efficient improvement of ILs, the high cost of raw material and complicated preparation process inhibit its further development to some extent.

More recently, DESs have been attracting numerous attentions, which consist of hydrogen bond acceptor (HBA) and hydrogen bond donor (HBD) via hydrogen-bonding interaction, and thus the melting point is obviously lower than either individual pure component ${ }^{24,25}$. The DESs exhibit excellent physical and chemical properties, such as low vapor pressure, relatively wide liquid range, non-flammable, conductivity, non-toxicity, sharing similar properties as ILs ${ }^{24-26}$. Moreover, DESs can be prepared easier with lower cost of raw materials, resulting in that DESs has emerged as the promising alternatives to ILs. Yu et al used acidic DES, consisting of trifluoromethanesulfonic acid (TfOH) and taurine (TAU), as the catalyst for $\mathrm{C} 4$ alkylation. They found that $[\mathrm{TfOH}]_{3}[\mathrm{TAU}] / \mathrm{PEG}-200$ catalytic system displays the encouraging increase in catalytic activity and selectivity with the $\mathrm{C}_{8}$ selectivity up to $85.54 \%^{27}$. However, the applications of DESs as additives in $\mathrm{C} 4$ alkylation still remain seldom. More importantly, there is no systematical report regarding to the effect of DESs additives on the catalytic and recycle performance of $\mathrm{H}_{2} \mathrm{SO}_{4}$ alkylation. In addition, the behaviors of DESs additives at the $\mathrm{H}_{2} \mathrm{SO}_{4} / \mathrm{C} 4$ hydrocarbons interface are still insufficient. Fortunately, molecular dynamics (MD) simulation is a powerful tool to probe the microscale interfacial properties, which has been well proved to be able to efficiently reveal the interfacial behaviors of ILs and surfactants additives at the $\mathrm{H}_{2} \mathrm{SO}_{4} / \mathrm{C} 4$ hydrocarbons interface in our previous papers ${ }^{7,15,18,28-32}$.

Therefore, in this paper, the effects of DESs additives on the catalytic performance and interfacial properties of $\mathrm{H}_{2} \mathrm{SO}_{4}$-catalyzed $\mathrm{C} 4$ alkylation were studied in details using experimental methods and MD simulation. The investigated DESs include choline chlorides-phenol (ChCl-Pho (1:2)), choline chloridesp-toluenesulfonic acid (ChCl-TsOH (1:1)), choline chlorides-benzoic acid (ChCl-BOA (1:2)), and choline chlorides-hydroxylamine hydrochloride $\left(\mathrm{ChCl}-\mathrm{NH}_{2} \mathrm{OH}^{*} \mathrm{HCl}(1: 2)\right)$. The effect of DESs concentration, reaction time, temperature and recycle times on the $\mathrm{C} 4$ alkylation were investigated systematically. Additionally, MD simulations were used to reveal the enhancement of (ChCl-Pho (1:2)), ChCl-TsOH (1:1), and ChCl-BOA (1:2) on the interfacial properties of $\mathrm{H}_{2} \mathrm{SO}_{4}$ alkylation. 


\section{METHODOLOGY}

\subsection{Materials}

All chemicals (AR grade) were purchased commercially and used as received. $\mathrm{H}_{2} \mathrm{SO}_{4}$ (A.R, 98 wt\%) was bought from Sinopharm Chemical Reagent Co., Ltd. Choline chlorides and carbon tetrachloride ([?]99.5\%) were purchased from Shanghai Titan Scientific Co., Ltd. Phenol ([?]99.0\%) and benzoic acid (99.5\%) were purchased from Shanghai Aladdin Biochemical Technology Co., Ltd. P-toluenesulfonic acid (99.0\%) and hydroxylamine hydrochloride (98.5\%) were purchased from Shanghai MackLin Biochemical Technology Co., Ltd. Isobutane/2-butene mixture (86.9/13.1 wt\%)was obtained from Shanghai Weichuang Standard Gas Analysis Technology Co., Ltd. Nitrogen (99.99\%) gas was purchased from Air Liquide (Shanghai) Gas Co., Ltd.

\subsection{Preparation of DESs}

$\mathrm{ChCl}$ was chosen as the HBA, and phenol (Pho), p-toluenesulfonic acid ( $\mathrm{TsOH}$ ), benzoic acid (BOA) and hydroxylamine hydrochloride $\left(\mathrm{NH}_{2} \mathrm{OH}^{*} \mathrm{HCl}\right)$ were selected as $\mathrm{HBD}$, respectively. The synthesis of DESs was carried out in a glass flask. The acceptor and donor of the hydrogen bond were mixed according to molar ratio of $1 / 2,1 / 1,1 / 2,1 / 2$ to prepare ChCl-Pho (1:2), ChCl-TsOH (1:1), ChCl-BOA (1:2), and ChCl$\mathrm{NH}_{2} \mathrm{OH}^{*} \mathrm{HCl}(1: 2)$, respectively, with the structures shown in Figure $1^{33-35}$. The mixtures were heated with stirring for $1 \mathrm{~h}$ after the appearance of homogeneous liquid phase in the oil bath.

\section{Hosted file}

image1.emf available at https://authorea.com/users/435862/articles/538597-effects-of-deepeutectic-solvents-on-h2so4-catalyzed-alkylation-combining-experiment-and-moleculardynamics-simulation

Figure 1. Structures of different DESs.

\subsection{Experimental process}

For the typical alkylation process, the reaction took place in a batch reactor with $1 \mathrm{~L}$ volume equipped with a cooling system. At first, the $180 \mathrm{ml} \mathrm{DESs} / \mathrm{H}_{2} \mathrm{SO}_{4}$ mixture was put into the reactor, in which the ratio of DESs to $\mathrm{H}_{2} \mathrm{SO}_{4}$ was set to be 0.5, 1.0, 3.0, 5.0 and $8.0 \mathrm{wt} \%$, respectively. Subsequently, the $\mathrm{N}_{2}$ gas was added to purge the reactor by three times to remove the air, after which the cooling system turned on to keep reaction temperature at the given temperature. The pressure in the reactor was controlled at $0.5 \mathrm{MPa}$ to maintain the $\mathrm{C} 4$ reactants as liquid phase. Then, $120 \mathrm{~mL}$ of isobutane/2-butene mixture with a given ratio were quickly injected into the reactor and the agitation started to work at the stirring rate of $3000 \mathrm{rpm}$ to achieve a well-distributed dispersion between $\mathrm{C} 4$ reactants phase and acid phase. After the reaction stopped, the products were collected and analyzed by GC after being extracted and separated from acid phase using carbon tetrachloride. The details of the analysis of the products displayed on our previous work ${ }^{18}$.

\subsection{MD simulation details}

The potential parameters and models of the concentrated $\mathrm{H}_{2} \mathrm{SO}_{4}$ and $\mathrm{C} 4$ reactants for MD simulations were from the same as our previous work. ${ }^{6,7}$ The $\mathrm{C} 4$ reactants model includes equivalent 2-butene and isobutane with size of $6.0 \times 6.0 \times 4.0 \mathrm{~nm}^{3}$. The size of $\mathrm{H}_{2} \mathrm{SO}_{4}$ model is $6.0 \times 6.0 \times 8.0 \mathrm{~nm}^{3}$, containing 2848 $\mathrm{H}_{2} \mathrm{SO}_{4}$ molecules, 84 hydronium ions, and 84 bisulphate ions. For the interfacial model, the sandwich-like models were constructed with pure $\mathrm{H}_{2} \mathrm{SO}_{4}$ model in the middle and pure $\mathrm{C} 4$ reactants model in the both sides. $2 \mathrm{~nm}$ gap between pure $\mathrm{H}_{2} \mathrm{SO}_{4}$ model and pure $\mathrm{C} 4$ reactants model was used to place DESs. The number of ChCl-Pho (1:2) in the gap are 6, 15, and 24, corresponding to the concentration of $1.0 \mathrm{wt} \%$, $3.0 \mathrm{wt} \%$, and $5.0 \mathrm{wt} \%$, respectively. For $\mathrm{ChCl}-\mathrm{TsOH}(1: 1)$, the number is 6, 16, and 26, respectively. For ChCl-BOA (1:2), the number is 6,12 , and 21 , respectively. Initially, the energy minimization of 5000 steps was carried out, followed by $8 \mathrm{~ns}$ canonical ( $N V T$ ) simulations at $298.2 \mathrm{~K}$ with nose-hoover thermostat. The isothermal-isobaric (NPT ) ensemble was further conducted for $10 \mathrm{~ns}$ to fully equilibrate configures. During the simulation, the number density distribution of each moiety was calculated every $2 \mathrm{~ns}$, and the 
configures were fully equilibrated after there are no apparent deviations for the density. At last, 6 ns $N V T$ was carried out for data collection of interest with the time steps of $2.0 \mathrm{fs}$. The semi-isotropic Parrinello Rahman barostat method on $z$ axis was used with 2.0 ps relaxation time at 1 bar for all the NPTensemble to keep the interface unchanged ${ }^{15}$.

For all the MD simulations, GROMACS software was employed with periodic boundary conditions (PBC) in three dimensions ${ }^{36}$. The Lennard-Jones interaction and Coulombic interaction were cut off at $1.2 \mathrm{~nm}$. All the covalent bonds related to hydrogen atoms were treated using the LINCS algorithm. Maxwell distribution was employed to obtain the initial atomic velocity. The particle grid Ewald method was used to treat longrange electrostatic interactions. The OPLS-AA was used to treat the interaction between the $\mathrm{DESs}, \mathrm{H}_{2} \mathrm{SO}_{4}$ and $\mathrm{C} 4$ hydrocarbons ${ }^{6,7,29}$. At the same time, the charges of the DESs were refitted based on the ChelpG method at the Basis set of 6-311++G(d,p) level with Gaussian 09 program $^{37}$.

\section{Results and discussions}

\subsection{Effect of DESs on reaction time}

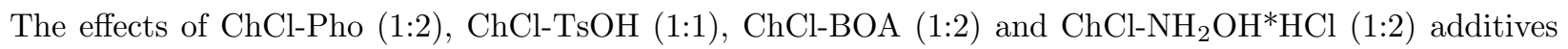
on the alkylate components as a function of time were initially investigated, as shown in Figure 2. At the initial time, the $\mathrm{C}_{9}+$ components are relatively high with the low conversion of $\mathrm{C}_{8}$ key components. With the extended reaction time, the RON and $\mathrm{C}_{8}$ key components increase gradually, and the LEs $\left(\mathrm{C}_{5}-\mathrm{C}_{7}\right)$ and $\mathrm{C}_{9}+$ components present a decreasing trend. The RON and $\mathrm{C}_{8}$ approach a plateau basically after 15 min, as same as the reaction time of $\mathrm{H}_{2} \mathrm{SO}_{4}$ system without any additive (see Figure S1). Among the reaction, the trimethylpentanes (TMPs) with higher RON (>100.0) grow in pace with the $\mathrm{C}_{8}$ components, leading to the higher RON of alkylate. Hence, the addition of DESs have no effect of the reaction time of $\mathrm{H}_{2} \mathrm{SO}_{4}$ alkylation in contrast to the pure $\mathrm{H}_{2} \mathrm{SO}_{4}$ system. The reaction time of 15 min was taken for the following experiments.

\section{Hosted file}

image2.emf available at https://authorea.com/users/435862/articles/538597-effects-of-deepeutectic-solvents-on-h2so4-catalyzed-alkylation-combining-experiment-and-moleculardynamics-simulation

Figure 2. Alkylate as a function of time with ChCl-Pho (1:2) (a), ChCl-TsOH (1:1) (b), ChCl-BOA (1:2) (c) and $\mathrm{ChCl}-\mathrm{NH}_{2} \mathrm{OH}^{*} \mathrm{HCl}(1: 2)$ (d) . Reaction conditions: temperature $281.2 \mathrm{~K}$, stirring rate $3000 \mathrm{r} / \mathrm{min}$, mass ratio of DESs $/ \mathrm{H}_{2} \mathrm{SO}_{4} 1.0 \mathrm{wt} \%$, volume ratio of $\mathrm{H}_{2} \mathrm{SO}_{4}$ /hydrocarbon 1.5:1, volume ratio of I/O 12:1.

\subsection{Effect of DES concentrations}

In order to explore the effect of the DES amounts on the alkylate components, ChCl-Pho (1:2) and ChCl$\mathrm{TsOH}(1: 1)$ additives were chosen. The alkylate components as a function of DESs concentrations are shown in Figure 3. From Figure 3a, the amount of ChCl-Pho (1:2) changes from $0 \mathrm{wt} \%$ to $5.0 \mathrm{wt} \%$ with the optimal mass ratio is about $1.0 \mathrm{wt} \%$, in which the $\mathrm{C}_{8}$ selectivity and TMPs components are $83.64 \%$ and $76.85 \%$, respectively, at the temperature of $281.2 \mathrm{~K}$. Meanwhile, with the amount of ChCl-Pho (1:2) increasing from $0 \mathrm{wt} \%$ to $0.5 \mathrm{wt} \%$, the LEs and $\mathrm{C}_{9}+$ components decrease slightly, and $\mathrm{C}_{8}$ and TMPs increase obviously, which demonstrates that $\mathrm{ChCl}$-Pho $(1: 2)$ has a promoting effect on the generation of $\mathrm{C}_{8}$ components to a considerable extent. When the amount of $\mathrm{ChCl}-\mathrm{Pho}(1: 2)$ increase from $0.5 \mathrm{wt} \%$ to $3.0 \mathrm{wt} \%$, the RON of alkylate reaches 97.30 , which is ascribed to the conversion of LEs and $\mathrm{C}_{9}+$ components to the TMPs with higher RON. However, when the amount of ChCl-Pho (1:2) reaches $5.0 \mathrm{wt} \%$, the catalytic effect significantly decreases, owing to the fact that excessive additives lead to the decrease of $\mathrm{H}_{2} \mathrm{SO}_{4}$ acidity for $\mathrm{C} 4$ alkylation. As we all know, the oligomerization of butene and the growth of red oil take place with the lower acidity of catalyst, which results in the increase of $\mathrm{C}_{9}+$ components and the decrease of key components dramatically ${ }^{38}$.

When ChCl-TsOH (1:1) is used as additives, the change of LEs, $\mathrm{C}_{8}$ and $\mathrm{C}_{9}+$ components follow the similar trend as that of $\mathrm{ChCl}-\mathrm{Pho}(1: 2)$. The difference is that the promoted catalytic performance of $\mathrm{ChCl}-\mathrm{TsOH}$ 
(1:1) is slightly weaker compared to ChCl-Pho (1:2). From Figure $3 b$, the optimal mass ratio is 1.0 wt\%, in which the RON is 96.93 and the $\mathrm{C}_{8}$ selectivity and TMPs components are $80.71 \%$ and $74.00 \%$, respectively, at the temperature of $281.2 \mathrm{~K}$. According to the previous work, Liu et al found that the addition of little amount of benzene for the C4 alkylation catalyzed by ILs could buffer the strong acidity of chloroaluminate anions to adjust acidity of catalysts and enrich the isobutane at the interface, which confirms that the addition of aromatics has a positive effect in $\mathrm{C} 4$ alkylation $^{39}$. Thus, it is inferred that the intensified catalytic performance of $\mathrm{ChCl}-\mathrm{Pho}(1: 2)$ and $\mathrm{ChCl}-\mathrm{TsOH}$ (1:1) additives probably comes from the phenol and $\mathrm{TsOH}$, the subclass of aromatics, respectively.

Figure $3 \mathrm{c}$ and $3 \mathrm{~d}$ plot the effect of the ChCl-Pho (1:2) and ChCl-TsOH (1:1) on the $\mathrm{C}_{8}$ components. Clearly, there is a dramatic influence on TMP components, which are 2,2,4-TMPs, 2,3,3-TMPs, and 2,2,3-TMPs. Particularly, at the optimal ratio, the 2,2,4-TMPs, 2,3,3-TMPs, and 2,2,3-TMPs have an increasing trend, which is consistent with the improvement of alkylate quality. In addition, ChCl-Pho (1:2) and ChCl-TsOH (1:1) have a little influence on 2,3,4-TMPs and DMHs, including 2,5-DMH, 2,4-DMH, and 2,3-DMH with lower RON. Therefore, the above results illustrate that the ChCl-Pho (1:2) and $\mathrm{ChCl}-\mathrm{TsOH}(1: 1)$ have a great effect on the conversion of LEs and HEs to TMPs with the higher selectivity of 2,2,4-TMPs, 2,3,3-TMPs and 2,2,3-TMPs. The enhancement of ChCl-Pho (1:2) and $\mathrm{ChCl}$-TsOH (1:1) additives on the quality of alkylate is inferred to be ascribed to improvement of interfacial properties, which will be explained systematically at the molecular level via MD simulation in the following sections.

\section{Hosted file}

image3.emf available at https://authorea.com/users/435862/articles/538597-effects-of-deepeutectic-solvents-on-h2so4-catalyzed-alkylation-combining-experiment-and-moleculardynamics-simulation

Figure 3. Alkylate components as a function of DESs concentrations. (a) and (c) for ChCl-Pho (1:2). (b) and (d) for ChCl-TsOH (1:1). Reaction conditions: temperature $281.2 \mathrm{~K}$, stirring rate $3000 \mathrm{r} / \mathrm{min}$, reaction time 15 min, volume ratio of $\mathrm{H}_{2} \mathrm{SO}_{4} /$ hydrocarbon 1.5:1, volume ratio of I/O 12:1.

\subsection{Effect of temperature}

$\mathrm{C} 4$ alkylation is an exothermic reaction. The low temperature is beneficial to the formation of $\mathrm{C}_{8}$ key components with higher $\mathrm{RON}^{40,41}$. Thus, the effect of reaction temperature on C4 alkylation from $281.2 \mathrm{~K}$ to $269.2 \mathrm{~K}$ with $\mathrm{ChCl}$-Pho (1:2) additive was listed in Table 1 . The difference of alkylate components between DESs-aiding systems and pure $\mathrm{H}_{2} \mathrm{SO}_{4}$ system as a function of temperature are shown in Figure 4 . For the system with $1.0 \mathrm{wt} \% \mathrm{ChCl}-\mathrm{Pho}(1: 2)$, it is clear that the targeted $\mathrm{C}_{8}$ components and the RON increase obviously from $83.77 \%$ at $281.2 \mathrm{~K}$ to $86.07 \%$ at $274.2 \mathrm{~K}, 97.39$ at $281.2 \mathrm{~K}$ to 98.27 at $274.2 \mathrm{~K}$, respectively, which is mainly attributed to lower reaction temperature. This tendency is in good agreement with our previous work, in which, lower temperature leads to a great increase in $\mathrm{C}_{8}$ contents and significant decrease in LEs, HEs and DMHs components ${ }^{15}$. However, in ChCl-Pho (1:2)-aiding system, when the temperature is below $274.2 \mathrm{~K}$, the quality of alkylate is not improved as expected. The $\mathrm{C}_{8}$ contents dramatically decrease and HEs sharply increase at the $269.2 \mathrm{~K}$. The $\mathrm{C}_{8}$ key components and the RON decrease obviously, and the content of $\mathrm{C}_{9}+$ components dramatically increase.

Table 1. Temperature-dependent alkylate components for $\mathrm{H}_{2} \mathrm{SO}_{4}$ alkylation with ChCl-Pho (1:2) as additive.

\begin{tabular}{|c|c|c|c|c|c|c|c|}
\hline Additive & Additive & $\begin{array}{l}\text { Alkylate } \\
\text { composi- } \\
\text { tion } \\
(\mathrm{wt} \%)\end{array}$ & $\begin{array}{l}\text { Alkylate } \\
\text { composi- } \\
\text { tion } \\
(\mathrm{wt} \%)\end{array}$ & $\begin{array}{l}\text { Alkylate } \\
\text { composi- } \\
\text { tion } \\
(\mathrm{wt} \%)\end{array}$ & $\begin{array}{l}\text { Alkylate } \\
\text { composi- } \\
\text { tion } \\
(\mathrm{wt} \%)\end{array}$ & $\begin{array}{l}\text { Alkylate } \\
\text { composi- } \\
\text { tion } \\
(\mathrm{wt} \%)\end{array}$ & $\begin{array}{l}\text { Alkylate } \\
\text { composi- } \\
\text { tion } \\
(\mathrm{wt} \%)\end{array}$ \\
\hline & Temp /K & $\mathrm{C} 5{ }^{\sim} \mathrm{C} 7$ & $\mathrm{C} 8$ & TMP & $\mathrm{C} 9+$ & $\mathrm{DMH}$ & $\mathrm{RON}$ \\
\hline Pure & 281.2 & 11.05 & 74.50 & 67.56 & 14.45 & 6.94 & 95.80 \\
\hline
\end{tabular}




\begin{tabular}{|c|c|c|c|c|c|c|c|}
\hline \multirow{5}{*}{$\begin{array}{l}\text { ChCl-Pho } \\
(1: 2)\end{array}$} & 281.2 & 6.46 & 83.77 & 76.98 & 9.77 & 6.79 & 97.39 \\
\hline & 277.2 & 6.07 & 85.65 & 79.45 & 8.28 & 6.20 & 98.05 \\
\hline & 274.2 & 5.62 & 86.07 & 80.15 & 8.30 & 5.92 & 98.27 \\
\hline & 273.2 & 4.65 & 84.21 & 78.67 & 11.14 & 5.54 & 97.86 \\
\hline & 269.2 & 6.67 & 71.20 & 67.31 & 22.12 & 3.89 & 95.74 \\
\hline
\end{tabular}

a Reaction conditions: ChCl-Pho (1:2) concentration $1.0 \mathrm{wt} \%$, stirring rate $3000 \mathrm{r} / \mathrm{min}$, reaction time 20 min, volume ratio of $\mathrm{H}_{2} \mathrm{SO}_{4}$ /hydrocarbon 1.5:1, volume ratio of I/O 12:1.

Furthermore, the difference of alkylate components and $\mathrm{C}_{8}$ components of $\mathrm{H}_{2} \mathrm{SO}_{4}$ alkylation with ChCl-Pho (1:2) additive as a function of temperature. From Figure 4a, compared with the pure $\mathrm{H}_{2} \mathrm{SO}_{4}$ system at $281.2 \mathrm{~K}$, the $\mathrm{C}_{8}$ contents and TMPs increase $9.27 \%, 11.15 \%, 11.57 \%$ and $9.71 \%, 9.42 \%, 11.89 \%, 12.59 \%$ and $11.11 \%$ at $281.2 \mathrm{~K}, 277.2 \mathrm{~K}, 274.2 \mathrm{~K}$, and $273.2 \mathrm{~K}$, respectively. In Figure 4b, 2,2,4-TMPs, 2,3,3-TMPs and 2,2,3-TMPs follow the similar trend as the $\mathrm{C}_{8}$ components, which suggests the change of the reaction temperature mostly impacts on the TMP components with higher RON.

\section{Hosted file}

image4.emf available at https://authorea.com/users/435862/articles/538597-effects-of-deepeutectic-solvents-on-h2so4-catalyzed-alkylation-combining-experiment-and-moleculardynamics-simulation

Figure 4. The difference of alkylate components between $\mathrm{H}_{2} \mathrm{SO}_{4}$ alkylation with ChCl-Pho (1:2) as a function of temperature (a). Temperature-dependent $\mathrm{C}_{8}$ components for $\mathrm{H}_{2} \mathrm{SO}_{4}$-catalyzed alkylation with ChCl-Pho (1:2) additive (b). Reaction conditions: ChCl-Pho (1:2) concentration $1.0 \mathrm{wt} \%$, stirring rate $3000 \mathrm{r} / \mathrm{min}$, reaction time $20 \mathrm{~min}$, volume ratio of $\mathrm{H}_{2} \mathrm{SO}_{4} /$ hydrocarbon 1.5:1, volume ratio of I/O 12:1.

\subsection{Lifetime of $\mathrm{H}_{2} \mathrm{SO}_{4}$ with DESs}

Based on the optimal reaction results at $281.2 \mathrm{~K}$, ChCl-Pho (1:2) and ChCl-TsOH (1:1) were chosen to probe the effect of DESs on the recycling capability for the $\mathrm{H}_{2} \mathrm{SO}_{4}$. The recycling run of $\mathrm{H}_{2} \mathrm{SO}_{4} / \mathrm{ChCl}-\mathrm{Pho}(1: 2)$, $\mathrm{H}_{2} \mathrm{SO}_{4} / \mathrm{ChCl}-\mathrm{TsOH}(1: 1)$ and pure $\mathrm{H}_{2} \mathrm{SO}_{4}$ are shown in Figure 5(a), Figure 5(b) and Figure S2, respectively. From Figure $5(\mathrm{a})$, the $\mathrm{RON}$ and $\mathrm{C}_{8}$ components slightly increase initially and then decrease slowly. The $\mathrm{C}_{9}{ }^{+}$components increase with the increased recycle times. The first 3 runs can be defined as catalytic activity strengthening stage. The RON and the $\mathrm{C}_{8}$ contents increase from 93.62 and $63.83 \%$ to 94.50 and $68.07 \%$, respectively. In the initial strengthening stage, the acidity of catalyst is still high to promote the main reactions. The trace amount of side reactions products of $\mathrm{H}_{2} \mathrm{O}$, esters and acid soluble oil (ASO) has a positive effect on $\mathrm{C} 4$ alkylation, which is the reason why the quality of alkylate is improved in first 3 times $^{42}$. Nevertheless, the $4^{\text {th }}-11^{\text {th }}$ recycles step into the gradual deactivation stage. The $\mathrm{C}_{8}$ contents and RON decrease from $66.00 \%$ and 93.78 to $51.23 \%$ and 90.90 , respectively. In this stage, the notorious side reactions products of $\mathrm{H}_{2} \mathrm{O}$, esters and ASO gradually accumulate with the increase of recycle times and leads to the gradual decrease in the acid strength and the quality of the alkylate. After $11^{\text {th }}$ runs, the catalyst tends to be inactive and the $\mathrm{C}_{9}+$ components dramatically increase from $36.77 \%$ to $53.55 \%$.

The lifetime performance of $\mathrm{H}_{2} \mathrm{SO}_{4}$ catalyst with ChCl-TsOH (1:1) additives is similar as that with ChCl-Pho (1:2) as additives. The first 2 recycle times is the stage of catalytic activity strengthening. After the 10 runs, the activity of catalyst dramatically decreases with RON down to 84.90 at 16 runs. The difference is the lifetime test with $\mathrm{ChCl}-\mathrm{TsOH}(1: 1)$ additives has a relatively stable high catalytic activity stage from $3^{\text {th }}$ to $10^{\text {th }}$. In high catalytic activity stage, the performance of the catalyst remains stable, the RON and the $\mathrm{C}_{8}$ contents is still above 93.0 and $63.00 \%$, respectively. In comparison to lifetime test of the pure $\mathrm{H}_{2} \mathrm{SO}_{4}$, however, the addition of ChCl-Pho (1:2) and ChCl-TsOH (1:1) do not improve the catalytic lifetime of $\mathrm{H}_{2} \mathrm{SO}_{4}$, although they show the effective catalytic performance,

\section{Hosted file}


image5.emf available at https://authorea.com/users/435862/articles/538597-effects-of-deepeutectic-solvents-on-h2so4-catalyzed-alkylation-combining-experiment-and-moleculardynamics-simulation

Figure 5. Alkylate components as a function of recycle times. (a) ChCl-Pho (1:2) at $1.0 \mathrm{wt} \%$. (b) ChClTsOH (1:1) at $1.0 \mathrm{wt} \%$. Reaction conditions: temperature $281.2 \mathrm{~K}$, stirring rate $3000 \mathrm{r} / \mathrm{min}$, reaction time 15 min, volume ratio of $\mathrm{H}_{2} \mathrm{SO}_{4}$ /hydrocarbon 1.5:1, volume ratio of $\mathrm{I} / \mathrm{O}$ 8:1.

\subsection{Distributions of DESs at the interface}

From the above experimental results, it is clear that the introduction of DESs can effectively increase the RON of alkylate, but the lifetime of $\mathrm{H}_{2} \mathrm{SO}_{4}$ catalyst was almost not promoted. It can be inferred that the better performance of alkylate is probably due to the intensification of acid/hydrocarbons interface, rather than the tunability of $\mathrm{H}_{2} \mathrm{SO}_{4}$ microenvironment. However, the effect of DESs on the acid/hydrocarbons interface remains unclear to a great extent. Thus, the acid/hydrocarbons interfacial behaviors with the addition of ChCl-Pho (1:2), ChCl-TsOH (1:1), and ChCl-BOA (1:2), respectively, were further investigated using MD simulations in details.

Initially, the equilibrated snapshots of DES distributions at different concentrations were presented in Figure 6. For all the systems, $\mathrm{ChCl}$ molecules were clearly observed with a better dispersion in $\mathrm{H}_{2} \mathrm{SO}_{4}$ phase, while the phenyl molecules, such as $\mathrm{Pho}, \mathrm{Ts} \mathrm{OH}$, and BOA molecules, tend to aggregate in the interfacial regions. Quantitatively, the mass density profiles along $z$ axis with DESs at different concentrations were displayed in Figure 7 and Figure S3. For the density profiles of different moieties of DESs, the distinct difference is that the phenyl molecules present an obvious peak in the interfacial regions, and the intensity of the peak becomes much larger with the increased DES concentrations. Conversely, $\mathrm{ChCl}$ molecules show a uniform distribution in the $\mathrm{H}_{2} \mathrm{SO}_{4}$ phase along $z$ axis. One can conclude that the phenyl molecules play the essentially important role in the tunability of acid/hydrocarbons interface. In addition, there is a larger peak intensity of $\mathrm{TsOH}$ molecules in the interfacial regions compared to Pho and BOA molecules at the same concentrations, suggesting the stronger aggregation of $\mathrm{TsOH}$ molecules at the interface. Moreover, the TsOH molecules stay closer to the $\mathrm{H}_{2} \mathrm{SO}_{4}$ phase than Pho and BOA molecules, probably due to the strong interaction between $\mathrm{SO}_{3} \mathrm{H}$ groups and $\mathrm{H}_{2} \mathrm{SO}_{4}$.
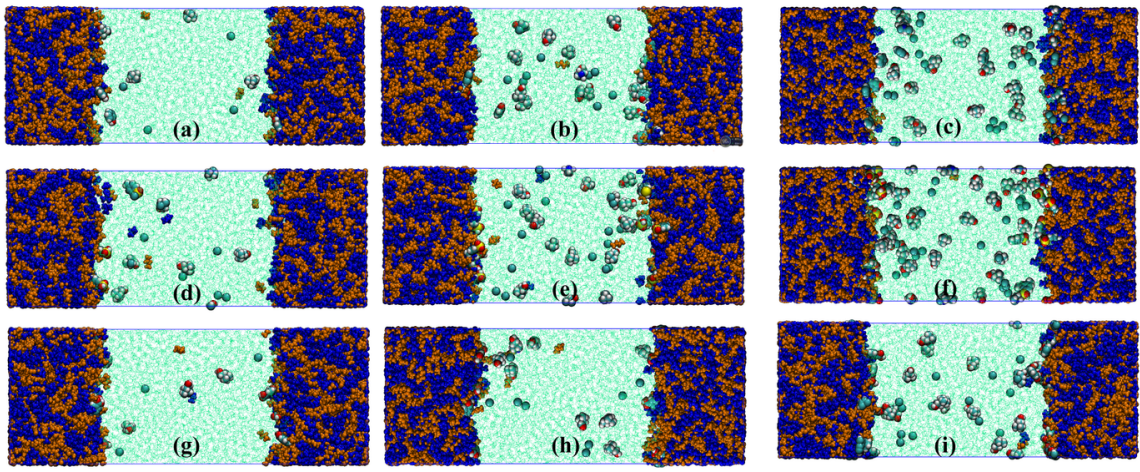

Figure 6. Equilibrated snapshots of DESs distributions with different concentrations at acid/hydrocarbons interface. (a), (b), and (c) ChCl-Pho (1:2) at $1.0 \mathrm{wt} \%, 3.0 \mathrm{wt} \%$, and $5.0 \mathrm{wt} \%$, respectively. (d), (e), and (f) $\mathrm{ChCl}-\mathrm{TsOH}(1: 1)$ at $1.0 \mathrm{wt} \%, 3.0 \mathrm{wt} \%$, and $5.0 \mathrm{wt} \%$, respectively. (g), (h), and (i) ChCl-BOA (1:2) at 1.0 $\mathrm{wt} \%, 3.0 \mathrm{wt} \%$, and $5.0 \mathrm{wt} \%$, respectively.

Green color represents the $\mathrm{H}_{2} \mathrm{SO}_{4}$ molecules in line style. Blue color represents isobutane molecules in VDW style. Brown color means 2-butene molecules in VDW style.

\section{Hosted file}


image7.emf available at https://authorea.com/users/435862/articles/538597-effects-of-deepeutectic-solvents-on-h2so4-catalyzed-alkylation-combining-experiment-and-moleculardynamics-simulation

Figure 7. Mass density profiles along $z$ axis of the simulated box with different DESs at different concentrations. (a), (b), and (c) ChCl-Pho (1:2) at $1.0 \mathrm{wt} \%, 3.0 \mathrm{wt} \%$, and $5.0 \mathrm{wt} \%$, respectively. (d), (e), and (f) $\mathrm{ChCl}-\mathrm{TsOH}(1: 1)$ at $1.0 \mathrm{wt} \%, 3.0 \mathrm{wt} \%$, and $5.0 \mathrm{wt} \%$, respectively.

\subsection{Interfacial thickness}

The capillary-wave theory can well describe the density of component A and B in the interfacial system ${ }^{43}$,

\section{Hosted file}

image8.wmf available at https://authorea.com/users/435862/articles/538597-effects-of-deepeutectic-solvents-on-h2so4-catalyzed-alkylation-combining-experiment-and-moleculardynamics-simulation

\section{(1)}

\section{Hosted file}

image9.wmf available at https://authorea.com/users/435862/articles/538597-effects-of-deepeutectic-solvents-on-h2so4-catalyzed-alkylation-combining-experiment-and-moleculardynamics-simulation

(2)

\section{Hosted file}

image10.wmf available at https://authorea.com/users/435862/articles/538597-effects-ofdeep-eutectic-solvents-on-h2so4-catalyzed-alkylation-combining-experiment-and-moleculardynamics-simulation

\section{Hosted file}

image11.wmf available at https://authorea.com/users/435862/articles/538597-effects-ofdeep-eutectic-solvents-on-h2so4-catalyzed-alkylation-combining-experiment-and-moleculardynamics-simulation

\section{Hosted file}

image12.wmf available at https://authorea.com/users/435862/articles/538597-effects-ofdeep-eutectic-solvents-on-h2so4-catalyzed-alkylation-combining-experiment-and-moleculardynamics-simulation

\section{Hosted file}

image13.wmf available at https://authorea.com/users/435862/articles/538597-effects-ofdeep-eutectic-solvents-on-h2so4-catalyzed-alkylation-combining-experiment-and-moleculardynamics-simulation

\section{Hosted file}

image14.wmf available at https://authorea.com/users/435862/articles/538597-effects-ofdeep-eutectic-solvents-on-h2so4-catalyzed-alkylation-combining-experiment-and-moleculardynamics-simulation 


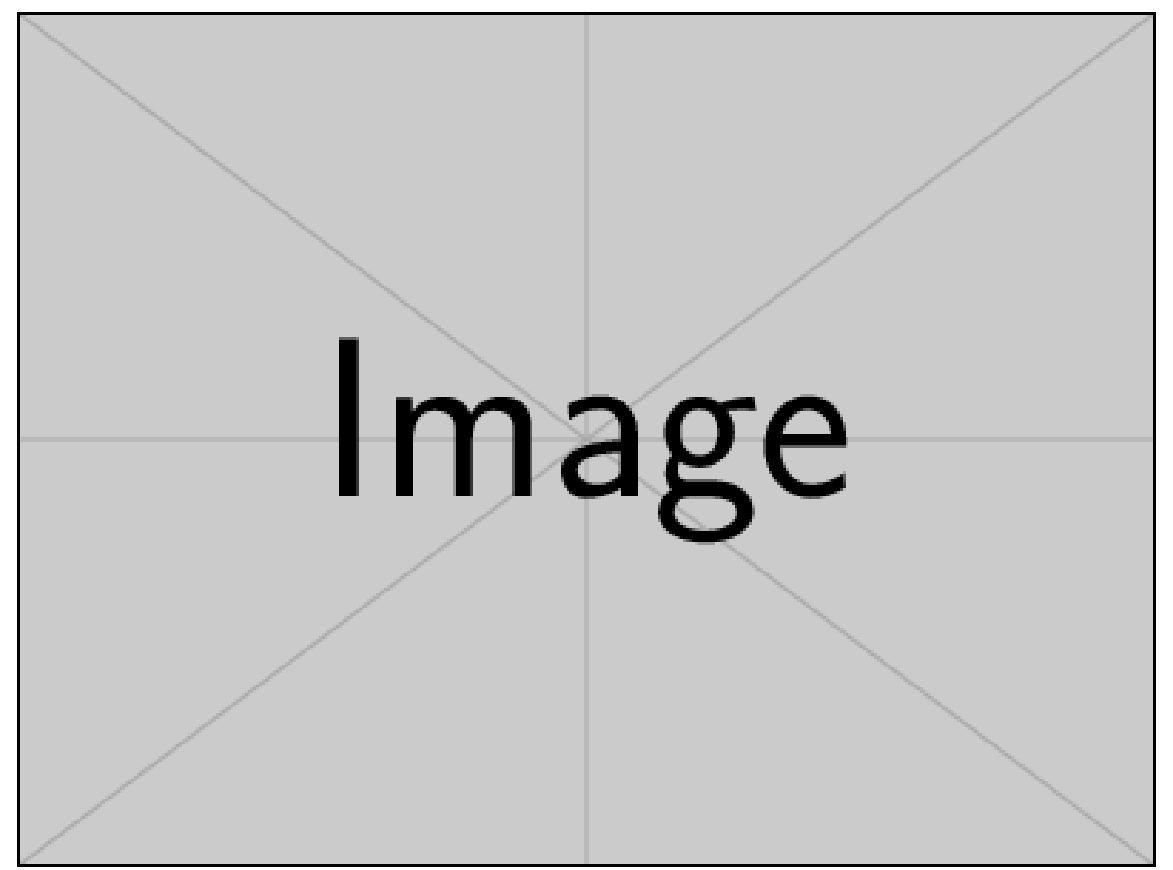

\section{Hosted file}

image15.wmf available at https://authorea.com/users/435862/articles/538597-effects-ofdeep-eutectic-solvents-on-h2so4-catalyzed-alkylation-combining-experiment-and-moleculardynamics-simulation

\section{Hosted file}

image16.wmf available at https://authorea.com/users/435862/articles/538597-effects-ofdeep-eutectic-solvents-on-h2so4-catalyzed-alkylation-combining-experiment-and-moleculardynamics-simulation

\section{Hosted file}

image17.wmf available at https://authorea.com/users/435862/articles/538597-effects-ofdeep-eutectic-solvents-on-h2so4-catalyzed-alkylation-combining-experiment-and-moleculardynamics-simulation

andmean the position of the Gibbs dividing surface of component $A$ and $B$, respectively.and represent component $A$ and $B$ bulk density, respectively.

is the contribution of thermal fluctuations to interfacial thickness. Using equation (1) and (2), the parameters,, and can be calculated. Thus, the interfacial intrinsic thickness () is obtained,

\section{Hosted file}

image18.wmf available at https://authorea.com/users/435862/articles/538597-effects-ofdeep-eutectic-solvents-on-h2so4-catalyzed-alkylation-combining-experiment-and-moleculardynamics-simulation

(3)

\section{Hosted file}


image19.wmf available at https://authorea.com/users/435862/articles/538597-effects-ofdeep-eutectic-solvents-on-h2so4-catalyzed-alkylation-combining-experiment-and-moleculardynamics-simulation

The total interfacial thickness () consists of the intrinsic width and thermal fluctuations using equation (4),

\section{Hosted file}

image20.wmf available at https://authorea.com/users/435862/articles/538597-effects-ofdeep-eutectic-solvents-on-h2so4-catalyzed-alkylation-combining-experiment-and-moleculardynamics-simulation

(4)

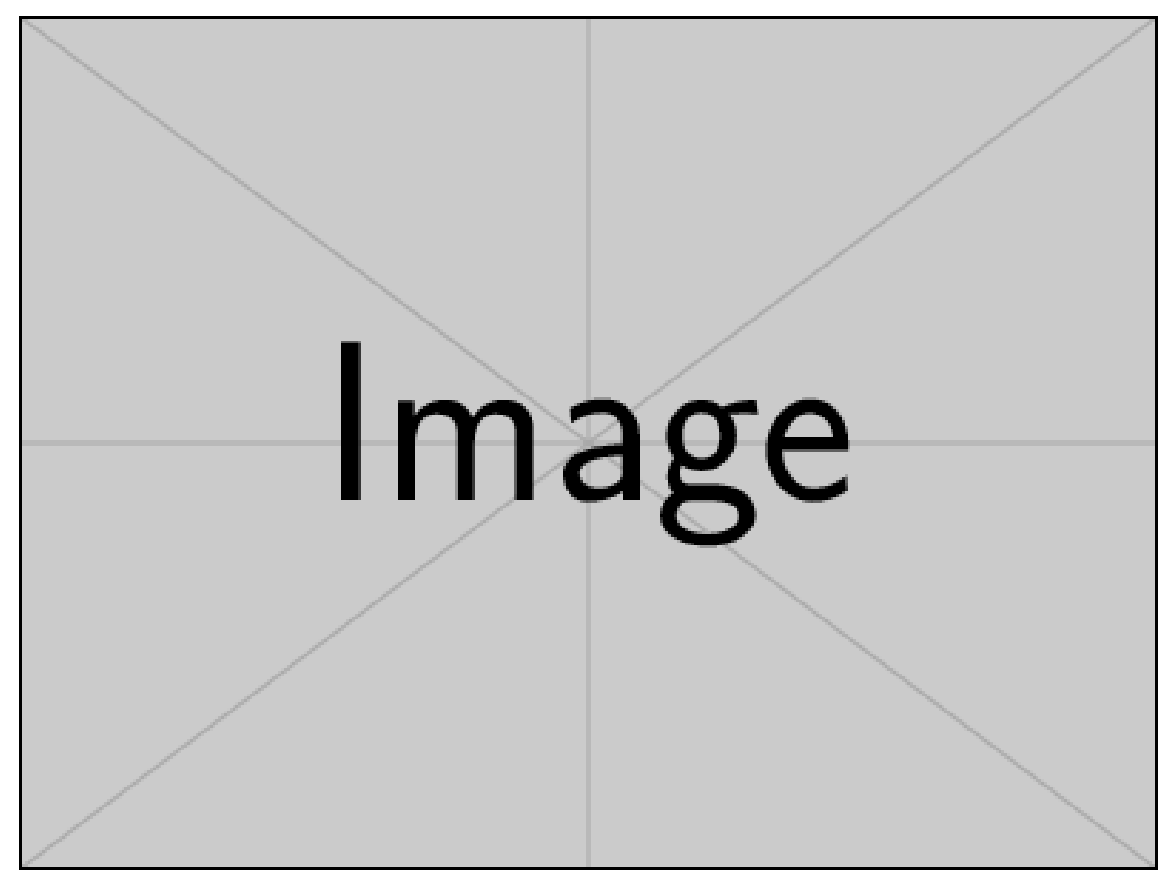



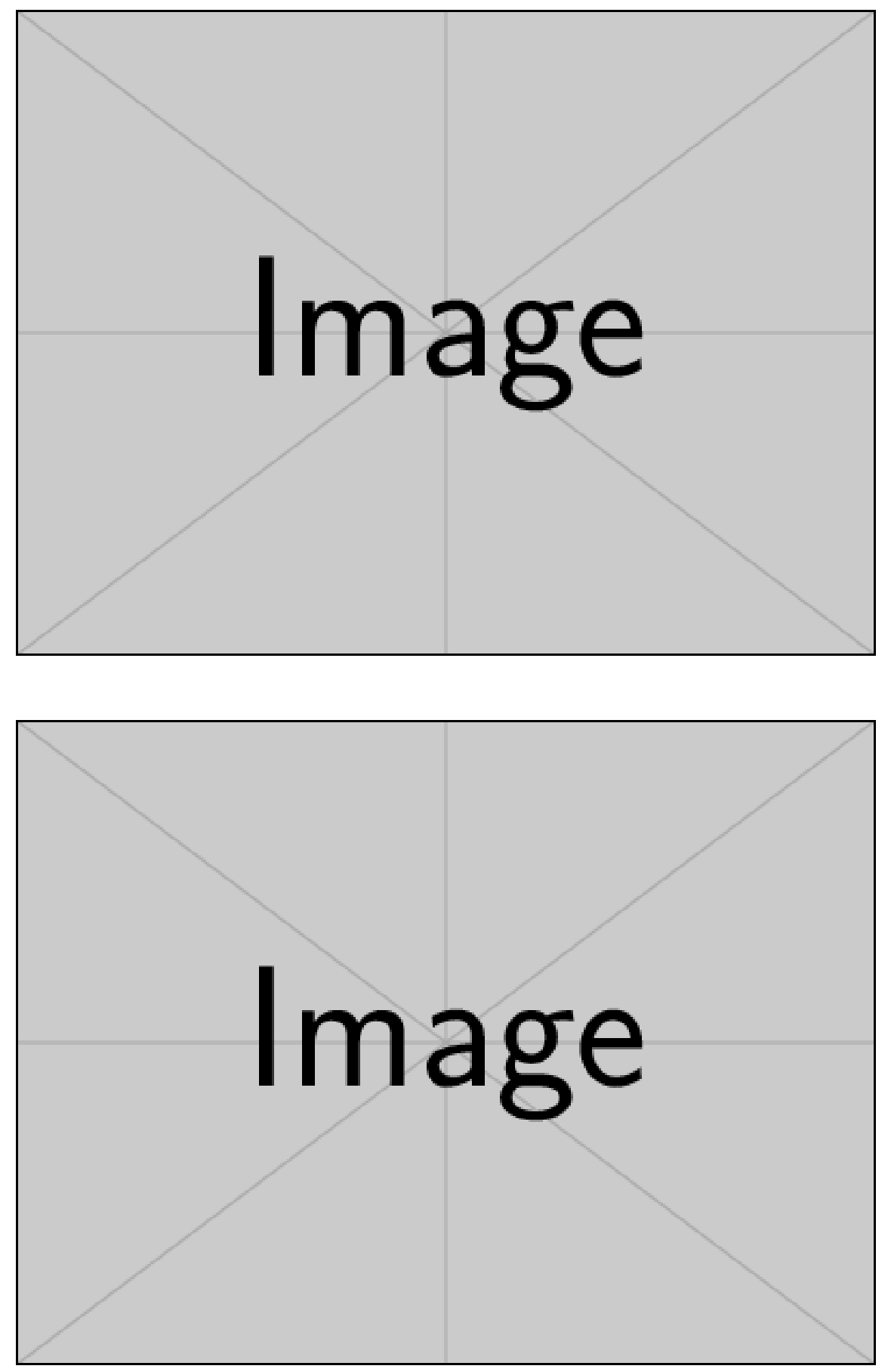

For the DESs-aiding systems, the density profiles of $\mathrm{H}_{2} \mathrm{SO}_{4}$ and MixC4 (isobutane + butene) are shown in Figure 8 and Figure S4, respectively. It is clearly seen that there is a good fitting for all the systems. The obtained

for different DESs as a function of concentrations as shown in Figure 8d. The of pure $\mathrm{H}_{2} \mathrm{SO}_{4}$ system is taken from our recent work as a benchmark ${ }^{15}$. The results indicate that the addition of DESs can significantly increase 
in comparison to the pure $\mathrm{H}_{2} \mathrm{SO}_{4}$ systems. Furthermore, the interfacial thickness rises along with the concentration of DESs. From experimental point of view, the enlargement of the interfacial thickness provides the larger interfacial reaction zones, which is better for higher-quality alkylate. At the same conditions, the ChCl-TsOH (1:1) additive can contribute more to the interfacial thickness compared to ChCl-Pho (1:2) and ChCl-BOA (1:2) additives.

\section{Hosted file}

image21.emf available at https://authorea.com/users/435862/articles/538597-effects-ofdeep-eutectic-solvents-on-h2so4-catalyzed-alkylation-combining-experiment-and-moleculardynamics-simulation

Figure 8. The fitting results of $\mathrm{H}_{2} \mathrm{SO}_{4}$ and MixC4 mass density for the calculation of interfacial thickness in the DES-aiding systems with different concentrations. (a), (b), and (c) ChCl-Pho (1:2) at $1.0 \mathrm{wt} \%$, $3.0 \mathrm{wt} \%$, and $5.0 \mathrm{wt} \%$, respectively. The obtained interfacial thickness for different DESs as a function of concentrations $(\mathrm{d})$.

\subsection{Interfacial compositions and diffusion}

To further study the effect of DESs on the interfacial behaviors of the MixC4 reactants, the interfacial compositions and diffusion coefficients of MixC4 reactants for different DES systems at different concentrations were calculated, as listed in Table 2. In the interfacial regions, there are almost no $\mathrm{ChCl} \mathrm{molecules,} \mathrm{while}$ the ratio of phenyl molecules increases as the concentrations of DESs. This observation is in good agreement with the finding from density profiles. Due to the higher ratio of phenyl molecules at higher concentration of DESs, the ratio of both isobutane and butene gradually declines as a function of concentration. However, the key point factor for alkylation is the ratio of isobutane to butene (I/O ratio) in the interfacial reaction zone. Meaningfully, the I/O ratio of all the systems with DESs additives are quite higher than that of pure $\mathrm{H}_{2} \mathrm{SO}_{4}$ system $(0.850)^{15}$. This strongly indicates that the DESs additives can significantly improve the $\mathrm{I} / \mathrm{O}$ ratio, which can restrain the oligomerization of butene, promote the hydride transfer, and thus lead to higher-quality of alkylate. For ChCl-Pho (1:2)-containing systems, the I/O ratio rises with the concentrations, while the opposite trend is found for ChCl-TsOH (1:1)- and $\mathrm{ChCl}-\mathrm{BOA}$ (1:2)-containing systems. For the dynamics, the diffusion coefficients ratio of isobutane to butene is also generally larger than that in pure $\mathrm{H}_{2} \mathrm{SO}_{4}$ system $(0.858)^{15}$. Thus, the introduction of DESs can promote the diffusion of isobutane with respect to butene, which is also helpful to restrain the oligomerization of butene, and promote the hydride transfer, resulting in higher-quality of alkylate. For different DESs, the diffusion coefficient ratio of isobutane to butene follows similar trend as the I/O ratio as a function of concentrations. To sum up, one can safely say that the DES additives can efficiently promote the solubility and diffusion of isobutane with respect to butene, and thus make positively contributions to the quality of alkylate.

Table 2. The interfacial compositions and interfacial diffusion coefficients of isobutane and butene, and the ratio of isobutane to butene for different DES systems at different concentrations.

\begin{tabular}{|c|c|c|c|c|c|c|c|c|}
\hline \multirow[t]{2}{*}{ Systems } & $\begin{array}{l}\text { Mass } \\
\text { fraction } \\
(\mathrm{wt} \%)\end{array}$ & $\begin{array}{l}\text { Interfacial } \\
\text { compositions }\end{array}$ & $\begin{array}{l}\text { Interfacial } \\
\text { compositions }\end{array}$ & $\begin{array}{l}\text { Interfacial } \\
\text { compositions }\end{array}$ & $\begin{array}{l}\text { Interfacial } \\
\text { compositions }\end{array}$ & $\begin{array}{l}\text { Diffusion } \\
\text { coefficients } \\
(\AA / \mathrm{ps})\end{array}$ & $\begin{array}{l}\text { Diffusion } \\
\text { coefficients } \\
(\AA / \mathrm{ps})\end{array}$ & $\begin{array}{l}\text { Diffusio } \\
\text { coeffici } \\
(\AA / \mathrm{ps})\end{array}$ \\
\hline & & $\begin{array}{l}\text { Phenyl } \\
\text { molecules }\end{array}$ & Butene & Isobutane & $\begin{array}{l}\text { Isobutane } \\
\text { /butene }\end{array}$ & Butene & Isobutane & $\begin{array}{l}\text { Isobuta } \\
\text { /butent }\end{array}$ \\
\hline \multirow{3}{*}{$\begin{array}{l}\text { ChCl- } \\
\text { Pho } \\
(1: 2)\end{array}$} & 1.0 & 0.0179 & 0.2452 & 0.2451 & 0.9999 & 0.2505 & 0.2150 & 0.8583 \\
\hline & 3.0 & 0.0380 & 0.2313 & 0.2412 & 1.0426 & 0. 2490 & 0.2156 & 0.8657 \\
\hline & 5.0 & 0.0640 & 0.2149 & 0.2328 & 1.0833 & 0.2423 & 0.2137 & 0.8818 \\
\hline $\begin{array}{l}\text { ChCl- } \\
\text { TsOH } \\
(1: 1)\end{array}$ & 1.0 & 0.0166 & 0.2400 & 0.2563 & 1.0679 & 0.2552 & 0.2295 & 0.8991 \\
\hline
\end{tabular}




\begin{tabular}{lllllllll} 
& 3.0 & 0.0490 & 0.2305 & 0.2460 & 1.0674 & 0.2447 & 0.2102 & 0.8590 \\
& 5.0 & 0.0808 & 0.2098 & 0.2238 & 1.0670 & 0.2418 & 0.2041 & 0.8441 \\
ChCl- & 1.0 & 0.0230 & 0.2259 & 0.2601 & 1.1514 & 0.2520 & 0.2183 & 0.8663 \\
BOA & & & & & & & & \\
$(1: 2)$ & & & & & & & & \\
& 3.0 & 0.0428 & 0.2215 & 0.2428 & 1.0961 & 0.2436 & 0.2080 & 0.8538 \\
& 5.0 & 0.0707 & 0.2178 & 0.2289 & 1.0507 & 0.2422 & 0.2066 & 0.8530 \\
\hline
\end{tabular}

\section{Conclusions}

The effect of several DESs on the quality of alkylate and the acid/hydrocarbons interfacial properties were investigated via experiments and MD simulations. It is found that the introduction of DESs almost has no impact on the reaction time. ChCl-Pho (1:2) displays the most outstanding catalytic performance with RON up to 97.37 and the $\mathrm{C}_{8}$ selectivity up to $83.64 \%$. The most suitable addition ratio for ChCl-Pho (1:2) and $\mathrm{ChCl}-\mathrm{TsOH}(1: 1)$ to $\mathrm{H}_{2} \mathrm{SO}_{4}$ is about $1.0 \mathrm{wt} \%$ with the improvement of $\mathrm{C}_{8}$ contents from $74.50 \mathrm{wt} \%$ in pure $\mathrm{H}_{2} \mathrm{SO}_{4}$ system at $281.2 \mathrm{~K}$ to $83.64 \mathrm{wt} \%$ and $80.71 \mathrm{wt} \%$ as well as the increase in RON from 95.80 to 97.37 and 96.93, respectively. However, the excessive addition of DESs leads to the decrease in reaction enhancement, which is attributed to reduction of the $\mathrm{H}_{2} \mathrm{SO}_{4}$ acidity. ChCl-Pho (1:2) and ChCl-TsOH (1:1) have a little influence on 2,3,4-TMPs and DMHs, including 2,5-DMH, 2,4-DMH, and 2,3-DMH with lower RON. However, both of them have a great effect on the conversion of LEs and HEs to TMPs. With the addition of ChCl-Pho (1:2), the targeted $\mathrm{C}_{8}$ components and the RON increase obviously from $83.77 \%$ at $281.2 \mathrm{~K}$ to $86.07 \%$ at $274.2 \mathrm{~K}, 97.39$ at $281.2 \mathrm{~K}$ to 98.27 at $274.2 \mathrm{~K}$, respectively, which is mainly contributed to low reaction temperature. The addition of ChCl-Pho (1:2) and ChCl-TsOH (1:1) show the effective catalytic performance, but both of them can not improve the catalytic lifetime of $\mathrm{H}_{2} \mathrm{SO}_{4}$ catalyst.

From MD simulations, the phenyl molecules, such as Pho, TsOH, and BOA molecules, is found to aggregate close to the interface with a higher density peak in the interfacial regions, which plays the essentially important role in the tunability of acid/hydrocarbons interface. The addition of DESs can significantly increase the interfacial thickness, promote the solubility and diffusion of isobutane with respect to butene in comparison to the pure $\mathrm{H}_{2} \mathrm{SO}_{4}$ system, thus making positively contributions to the quality of alkylate.

\section{Acknowledgements}

The financial support by the fellowship of China Postdoctoral Science Foundation (2020M681205 and 2021T140205), Shanghai Post-doctoral Excellence Program (2020135), National Natural Science Foundation of China (61988101), and 111 project (B20031) are gratefully acknowledged.

\section{Conflict of interest}

The authors declare no competing interests.

\section{References}

1. Velazquez HD, Likhanova N, Aljammal N, Verpoort F, Martinez-Palou R. New Insights into the Progress on the Isobutane/Butene Alkylation Reaction and Related Processes for High-Quality Fuel Production. A Critical Review. Energ. Fuel. Dec 2020;34(12):15525-15556.

2. Kore R, Scurto AM, Shiflett MB. Review of Isobutane Alkylation Technology Using Ionic Liquid-Based Catalysts-Where Do We Stand? Ind. Eng. Chem. Res. Sep 2020;59(36):15811-15838.

3. Wang H, Meng XZ, Zhao GY, Zhang SJ. Isobutane/butene alkylation catalyzed by ionic liquids: a more sustainable process for clean oil production. Green Chem. Mar 2017;19(6):1462-1489.

4. Gan PX, Tang SW. Research progress in ionic liquids catalyzed isobutane/butene alkylation. Chin. J. Chem. Eng. Nov 2016;24(11):1497-1504. 
5. Minnick DL, Kore RR, Lyon CJ, Subramaniam B, Shiflett MB, Scurto AM. Understanding Sulfur Content in Alkylate from Sulfuric Acid-Catalyzed C3/C4 Alkylations. Energ. Fuel. Apr 2019;33(5):4659-4670.

6. Sun WZ, Zheng WZ, Cao P, Zhao L. Probing interfacial behaviors of Bronsted acidic ionic liquids improved isobutane alkylation with C4 olefin catalyzed by sulfuric acid. Chem. Eng. J. Dec 2019;377:119744.

7. Zheng WZ, Cao P, Yuan Y, et al. Experimental and modeling study of isobutane alkylation with C4 olefin catalyzed by Bronsted acidic ionic liquid/sulfuric acid. Chem. Eng. J. Dec 2019;377:119578.

8. Costa BOD, Querini CA. Isobutane alkylation with butenes in gas phase. Chem. Eng. J. Aug 2010;162(2):829-835.

9. Dalla Costa BO, Querini CA. Isobutane alkylation with solid catalysts based on beta zeolite. Appl. Catal. A-Gen. Sep 2010;385(1-2):144-152.

10. Sievers C, Liebert JS, Stratmann MA, Olindo R, Lercher JA. Comparison of zeolites LaX and LaY as catalysts for isobutane/2-butene alkylation. Appl. Catal. A-Gen. Mar 2008;336(1-2):89-100.

11. Guzman A, Zuazo I, Feller A, Olindo R, Sievers C, Lercher JA. Influence of the activation temperature on the physicochemical properties and catalytic activity of La-X zeolites for isobutane/cis-2-butene alkylation. Microporous Mesoporous Mat.Dec 2006;97(1-3):49-57.

12. Sheng XL, Wang BB, Mao CF, Sha X, Zhou YM. Influence of $\mathrm{FeCl}_{3}$-modified chloroaluminate ionic liquids on long-chain alkenes alkylation. Appl. Organomet. Chem. Jan 2021;35(1):11.

13. Li LT, Zhang JS, Wang K, Luo GS. Caprolactam as a New Additive To Enhance Alkylation of Isobutane and Butene in $\mathrm{H}_{2} \mathrm{SO}_{4}$. Ind. Eng. Chem. Res. Dec 2016;55(50):12818-12824.

14. Ren H, Zhao G, Zhang S, Cui P, Huang J. Triflic acid catalyzed isobutane alkylation with trifluoroethanol as a promoter.Catal Commun. Feb 10 2012;18:85-88.

15. Zheng WZ, Wang Z, Sun WZ, Zhao L, Qian F. $\mathrm{H}_{2} \mathrm{SO}_{4}$-catalyzed isobutane alkylation under low temperatures promoted by long-alkyl-chain surfactant additives. AIChE J . DOI:10.1002/aic.17349.

16. Li XF, Kunieda H. Catanionic surfactants: microemulsion formation and solubilization. Curr. Opin. Colloid Interface Sci.Nov 2003;8(4-5):327-336.

17. Chen WS. Solubility measurements of isobutane/alkenes in sulfuric acid: applications to alkylation. Appl. Catal. A-Gen.Dec 2003;255(2):231-237.

18. Zheng WZ, Li D, Sun WZ, Zhao L. Multi-scale modeling of isobutane alkylation with 2-butene using composite ionic liquids as catalyst. Chem. Eng. Sci. Aug 2018;186:209-218.

19. Liu RX, Zhang P, Zhang SJ, Yan T, Xin JY, Zhang XP. Ionic liquids and supercritical carbon dioxide: green and alternative reaction media for chemical processes. Rev. Chem. Eng. Dec 2016;32(6):587-609.

20. Kumar P, Vermeiren W, Dath JP, Hoelderich WF. Production of alkylated gasoline using ionic liquids and immobilized ionic liquids. Appl. Catal. A-Gen. May 2006;304(1):131-141.

21. Wang AY, Zhao GY, Liu FF, Ullah L, Zhang SJ, Zheng AM. Anionic clusters enhanced catalytic performance of protic acid ionic liquids for isobutane alkylation. Ind. Eng. Chem. Res. Aug 2016;55(30):82718280 .

22. Liu Y, Li R, Sun HJ, Hu RS. Effects of catalyst composition on the ionic liquid catalyzed isobutane/2butene alkylation. J. Mol. Catal. A-Chem. Mar 2015;398:133-139.

23. Tang SW, Scurto AM, Subramaniam B. Improved 1-butene/isobutane alkylation with acidic ionic liquids and tunable acid/ionic liquid mixtures. J. Catal. Dec 2009;268(2):243-250.

24. Zhang QH, Vigier KD, Royer S, Jerome F. Deep eutectic solvents: syntheses, properties and applications. Chem. Soc. Rev.2012;41(21):7108-7146. 
25. Abbott AP, Boothby D, Capper G, Davies DL, Rasheed RK. Deep eutectic solvents formed between choline chloride and carboxylic acids: Versatile alternatives to ionic liquids. J. Am. Chem. Soc. Jul 2004;126(29):9142-9147.

26. Smith EL, Abbott AP, Ryder KS. Deep Eutectic Solvents (DESs) and Their Applications. Chem. Rev. Nov 2014;114(21):11060-11082.

27. Yu F-L, Gu Y-L, Gao X, Liu Q-C, Xie C-X, Yu S-T. Alkylation of isobutane and isobutene catalyzed by trifluoromethanesulfonic acid-taurine deep eutectic solvents in polyethylene glycol. Chem. Comm. Apr 2019;55(33):4833-4836.

28. Zheng WZ, Wang HY, Xie WX, Zhao L, Sun WZ. Understanding interfacial behaviors of isobutane alkylation with C4 olefin catalyzed by Sulfuric Acid or Ionic Liquids. AIChE J. Mar 2018;64(3):950-960.

29. Zheng WZ, Huang CZ, Sun WZ, Zhao L. Microstructures of the Sulfonic Acid-Functionalized Ionic Liquid/Sulfuric Acid and Their Interactions: A Perspective from the Isobutane Alkylation. J. Phys. Chem. B. Feb 2018;122(4):1460-1470.

30. Zheng WZ, Cao P, Sun WZ, Zhao L. Towards an understanding of the microstructure and interfacial properties of the ionic liquid/sulfuric acid catalyst in liquid-liquid reactions. Chem. Eng. Sci. Sep 2019;205:287-298.

31. Zheng WZ, Xie WX, Sun WZ, Zhao L. Modeling of the interfacial behaviors for the isobutane alkylation with C4 olefin using ionic liquid as catalyst. Chem. Eng. Sci. Jul 2017;166:42-52.

32. Sun WZ, Zheng WZ, Xie WX, Zhao L. Understanding Structure-Property Relationship of SO3HFunctionalized Ionic Liquids together with Sulfuric Acid in Catalyzing Isobutane Alkylation with C4 Olefin. Ind. Eng. Chem. Res. Nov 2018;57(45):15310-15318.

33. Zhou XL, Huang TJ, Liu J, et al. Recyclable deep eutectic solvent coupling sodium hydroxide posttreatment for boosting woody/herbaceous biomass conversion at mild condition. Bioresour. Technol. Jan 2021;320:12437.

34. Khezeli T, Daneshfar A. Synthesis and application of magnetic deep eutectic solvents: Novel solvents for ultrasound assisted liquid-liquid microextraction of thiophene. Ultrason. Sonochem.Sep 2017;38:590-597.

35. Aroso IM, Silva JC, Mano F, et al. Dissolution enhancement of active pharmaceutical ingredients by therapeutic deep eutectic systems. Eur. J. Pharm. Biopharm. Jan 2016;98:57-66.

36. Van der Spoel D, Lindahl E, Hess B, Groenhof G, Mark AE, Berendsen HJC. GROMACS: Fast, flexible, and free. J. Comput. Chem. Dec 2005;26(16):1701-1718.

37. Frisch M, Trucks G, Schlegel HB, et al. gaussian 09, Revision d. 01, Gaussian. Inc., Wallingford CT. $2009 ; 201$.

38. Huang Q, Zhao G, Zhang S, Yang F. Improved Catalytic Lifetime of $\mathrm{H}_{2} \mathrm{SO}_{4}$ for Isobutane Alkylation with Trace Amount of Ionic Liquids Buffer. Ind. Eng. Chem. Res. 2015;54(5):1464-1469.

39. Liu Y, Wu GQ, Hu RS, Gao GJ. Effects of aromatics on ionic liquids for C-4 alkylation reaction: Insights from scale-up experiment and molecular dynamics simulation. Chem. Eng. J. Dec 2020;402:126252.

40. Wang HY, Ma S, Zhou ZM, Li MJ, Wang H. Alkylation of isobutane with butene catalyzed by deep eutectic ionic liquids.Fuel. Jun 2020;269:117419.

41. Liu ZC, Meng XH, Zhang R, Xu CM, Dong H, Hu YF. Reaction performance of isobutane alkylation catalyzed by a composite ionic liquid at a short contact time. AIChE J. Jun 2014;60(6):2244-2253.

42. Xin $\mathrm{Y}, \mathrm{Hu} \mathrm{Y}, \mathrm{Li} \mathrm{M}$, et al. Isobutane Alkylation Catalyzed by $\mathrm{H}_{2} \mathrm{SO}_{4}$ : Effect of $\mathrm{H}_{2} \mathrm{SO}_{4}$ Acid Impurities on Alkylate Distribution. Energy \& Fuels. Dec 2021;35(2):1664-1676. 
43. Riedleder AJ, Kentish SE, Perera JM, Stevens GW. Structural investigation of a water/n-heptane interface: A molecular dynamics study. Solvent Extr. Ion Exch. Feb 2007;25(1):41-52. 